\title{
Displays of Colonial Shame in Puerto Rican Reggaetón
}

\author{
Alison Torres-Ramos
}

Yo soy el que nadie entiende, el loco demente,
la voz del pueblo,
el más buena gente,todo lo que yo te hable va a ser desagradable,
muy inteligente y supuestamente, poco saludable.
Gracias a mis insultos,
los niños tienen que escucharme bajo la supervisión de un adulto[1]

— Calle 13 "Ven y Critícame"

\begin{abstract}
Yo no planto bandera pues yo no soy Cristóbal Colon, yo soy de Las Acacias cien por ciento de corazón, de ningún caserío yo me quiero hacer dueño, no soy un extranjero soy puertorriqueño[2].

— Vico C "La Recta Final”
\end{abstract}

It was summer 2004 in Puerto Rico, I had just gotten my hands on the new Barrio Fino CD, and I was on my way to the local Sam's Club in Ponce to meet Daddy Yankee. I was ecstatic on the way there and blasted the CD as loud as it could go in the car. I arrived about two hours early and the dense line, made up of equally exited fans, stretched around inside and outside the door. I never got to meet Daddy Yankee because he decided to leave (after several hours) before it was my turn. I, and the countless other fans who left Sam's Club that day without an autograph or picture, were not bitter. We played our CDs loudly on the way back home and were not ashamed to love reggaetón[3]. Fast forward to Puerto Rico today, and while reggaetón is still fairly popular at parties or at local youth hangouts, the love for reggaetón has greatly decreased on the island. Gone are the days when people were not ashamed of liking the genre. Now, listeners of reggaetón are stereotyped as being without morals, overly sexual, and having criminal inclinations. Reggaetón is still a popular genre in the wider Latin American community, as evidenced by the numerous reggaetón artists that appear on popular TV shows, such as Nuestra Belleza Latina, and by the reggaetón artists who still win music awards and whose music tops the charts. Why is this acceptance of the genre by the wider Latina community not a reflection of Puerto Rican sentiments?

Radio stations, music videos, and elaborate concerts are just some of the ways that music is part of the burgeoning culture industry. With its entertaining yet innocent façade, the music industry has covertly helped shape many aspects of contemporary culture, such as fashion trends, personal identity, and even media production styles, to name a few. According to Debord (1970), spectacles refer to media events that are produced by the culture industry and are designed to influence audience behavior in order to maintain their hegemonic relationship with the ruling class. I use Kellner's (2003) diagnostic critique as my methodological framework. Kellner explains that "The conception of cultural studies as a diagnostic critique thus combines using social theory to interpret and contextualize phenomena of media culture with developing close readings and situating of cultural texts to elucidate contemporary culture and society" (29). This framework facilitates the analysis of the rise and fall of reggaetón because it provides insights into 
how the culture industry shapes the perception of the genre among the Puerto Rican population.

I believe that the key to unraveling this peculiar phenomena is to understand that Puerto Rican's changing acceptance of reggaetón has an adverse relationship with the culture industry's standardization of the genre, coupled with Puerto Rico's unique relationship with colonial shame. Rivera et al. (2009) explains that "reggaeton is neither hiphop nor dancehall nor Latin nor tropical in the traditional sense, yet it draws from all of these (and forges imagined connections with them) in projecting a discursive, resonant sound" (8). She also contends that reggaetón, with "Its suggestive sonic and cultural profile has animated contentious debates around issues of race, nation, class, gender, sexuality, and language" (1). While it is true that reggaetón originally gained popularity among lower-class youth, this does not represent the characteristics of the wider audience. Much like hip-hop, which was characterized by its "blackness" but whose main audience was white suburban male teenagers (Rose 1994), reggaetón is characterized as a lower class Puerto Rican genre, despite its success in the general Latino market, which cuts across economic barriers.

I chose to focus on Puerto Rican reggaetón over other international manifestations of this genre due to Puerto Rico's tumultuous colonial history coupled with its uncertain political status, which has resulted in a phenomenon called Puerto Rican shame. Negrón Muntaner (2004) argues that Puerto Rican attempts to value themselves have "frequently been staged through spectacles to offset shame" and that Boricua identity as we know it would not exist without the "shame" of being Puerto Rican (xiv). This shame is not the product of an individual inferiority complex, but rather a mechanism that constitutes "social identities generated by conflict within asymmetrical power relations" (xiii). Puerto Ricans have historically been disadvantaged due to their constant colonial status since the fifteenth century. Boricua identities have been produced in a political environment marked by various "sites of 'colonial' shame" in which Puerto Ricans have been degraded; as a result, Puerto Rican pride is not a freely chosen affirmation but the "effect of a subjection" (6). Puerto Rico is a colony whose residents are born American but who are second class citizens due to not having the same rights as their mainland counterparts, such as the right to vote in a Presidential election, despite being allowed to vote in primaries. Since the identity that defines itself as a source of special pride is so closely tied to shame, the identity is "constitutively shameful" and is, inevitably, an "ambivalent" identity (8). Many Puerto Ricans proudly uphold their Boricua ethno national status, despite the fact that they are legally Americans. I believe that Puerto Rican colonial shame was a key factor in the massive popularity of the reggaetón spectacle in the early 2000 s.

The culture industry's one-dimensional representation of Puerto Rican reggaetón was increasingly degrading, which played a role in how Boricua's viewed the genre. For the most part, the current media in Puerto Rico has distanced themselves from reggaetón in order to dis-associate themselves with the negative stereotypes accompanying the spectacle of reggaetón. Negron-Muntaner (2004) states that the most vital cultural productions that deal with Boricua identity have "sprung not from the denial of shame, but from its acknowledgment into wounds that we can be touched by" (xvvi). Puerto Ricans readily appropriated themselves as the original reggaetón artists in the genre's heyday. Nonetheless reggaetón took a turn, much like hip hop did in the nineties. Agger (1992) states that "The ideological outcomes of the culture industry are in a sense unintended; they emerge in the interplay of authorial, directorial, and audience assumptions about the nature of the world" (65). Hart (2009) expands on Agger's idea to assert that "the effect of the culture industry's cycle of assumptions on the one-dimensional representation of hip hop music and its reflection and reinforcement of Whites' perceptions of Blacks and Black Culture. The reinforcement of Whites' historically negative racial attitudes emerge unintended through a complex cycle of assumptions between the director (culture industry), the author (hip hop artist), and the audience (White consumers)" (v). These same assumptions apply to the one-dimensional representation of reggaetón in Puerto Rico. The difference is that instead of white culture devaluing black culture, Puerto Ricans base their evaluation of the genre on negative stereotypes revolving around poor people who live in public housing projects. Therefore, the director remains the culture industry, but the author becomes the reggaetón artist, and the audience is the middle to upper class Puerto Ricans, irrespective of the color of their skin.

Reggaetón fell out of favor with the wider Puerto Rican public after its boom in 2005. Critics publicly accused reggaetón of not being creative because all of the songs in the genre use the same rhythmic beat and they argued that reggaetón aggressively promoted sex, violence, and drugs, which made the genre a bad influence on the general public. These same critiques against reggaetón mirror the public discourse, which attacks the urban poor and is not based on fact. Reggaetón artists readily accept that their music was originally widely accepted by lower class youths, but a great quantity of reggaetón fans come from different social classes and racial backgrounds.

Puerto Ricans were eager to be the face of a widely successful and promising new musical genre that boasted 
audiences from diverse cultures and social statuses. Puerto Rican reggaetón is worthy of study as part of the hip hop diaspora because it was originally Puerto Rican artists who put the genre on the international map (Chosen Few 2005). Puerto Rican artists such as Don Omar and Daddy Yankee brought reggaetón to the mainland and made it popular among the Latino/a population. Early optimism for reggaetón reached its height in the mid-2000s. This hype led to talk that it could replace Spanish hip-hop and influenced the creation of many reggaetón-only radio stations and production companies both in Puerto Rico and in the United States. Reggaetón made the top of the popular playlists and artists won prestigious music awards, such as Daddy Yankee, who won the Latin Grammy, the Billboard Music Award, and the ALMA Award in 2005.

I divide the Reggaetón into two phases: underground reggaetón and mainstream reggaetón ("Vico C Still Holds it Down" 2006). Reggaetón is typically defined as music that has the characteristic "boom-ch-boom-chick" drum rhythm (Marshall 2010). However, due to current trends in the expansion of the genre, it is now typically called música urbana and includes music with various rhythms. I agree with the inclusive term música urbana because I think that a genre can have various rhythms, but for the purposes of this essay, I will refer to the collective genre of música urbana as reggaetón in order to stay true the genre's origin.

The first phase of the genre, which I call old school reggaetón, spans roughly from the early nineties too early 2004. According to the documentary The Chosen Few (2005), reggaetón as a genre had its origin in Panama in 1989 with artists such as El General, Nando Boom and Pocho Pan, who combined Jamaican reggae beats with Spanish lyrics. Its unique characteristic rhythm, however, became popular in the 90s and had roots in dancehall reggae, particularly with the song "Dem Bow" by Jamaican Shabba Ranks. Marshall (2008) elaborates by explaining that in reggaetón, the "features that more audibly connect dancehall reggae-most commonly and recognizably defined by its minimal $3+3+2$ drum rhythms - to the harmonic and melodic conventions of the roots of reggae tradition" (135). According to longwoof.com, old school reggaetón featured dembow prominently.

According to the documentary, The Noise by Dj Negro (2003), Puerto Ricans in the early 90s were eager to get new music from Panama, but they could not because communication between both countries was scarce and difficult. DJ Negro took the initiative of opening The Noise nightclub in San Juan in order to cater to the needs of the audience. He came up with the idea of taking Panamanian instrumental records and recording over them with Puerto Rican artists. This opened up the genre in Puerto Rico by allowing previously inexperienced artists to participate in the creation of reggaeton and Spanish hip hop. The resulting music became immensely popular in the underground music scene. DJ Negro became a music producer sought after by young talent, including Vico C, who became the "self-described 'philosopher of reggaeton"' (Billows 2005). During this underground phase, the reggaetón genre, specifically the artists, enjoyed greater autonomy. According to Vico $\mathrm{C}$ in the documentary The Chosen Few (2005), the public was tired of listening to the standardized music produced by the industry. Once they saw the realness of the underground movement, they became loyal and adopted it.

Reggaetón arrived in Puerto Rico in the early-nineties and gained popularity with artists and producers such as DJ Negro, DJ Playero, and DJ Erick in conjunction with support from major dance clubs such as The Noise in San Juan. The underground nature of reggaetón in Puerto Rico was seminal to its development. Puerto Ricans were influenced by east coast hip hop due to their political status, which gave them easy access to the music ("Reggaeton" n.d.). The distribution of the music was primarily taken up by lower and middle class youths, who in turn supported the dance clubs that played the genre ("Reggaeton Music" n.d.). The timing of the height of genre was fortuitous because Spanish rap had become popular around the same time, with artists such as Vico C. Reggaetón began in the underground scene but eventually propelled into American popularity after its introduction to the New York, Chicago, and Miami dance clubs. Reggaetón became mainstream with N.O.R.E.'s "Oye Mi Canto" and Daddy Yankee's "Gasolina" in 2004 ("Reggaeton" n.d.).

Similar to the development of the country music genre (Peterson 1997), in the early days of reggaetón, the genre was not mediated by the culture industry, which led to greater creative freedom. Underground reggaetón tracks featured creative lyrics that had a mixture of topics, including those designed to protest violence and inequality, like for example, "Mataron a un Inocente" [They Killed an Innocent Person] by the duo Héctor y Tito[4]. In the song, they appeal to the audience to stop violent crimes. This song reverses the dehumanizing tendency of street violence by providing a pathos-based description of the effects of violent acts. They remind everyone that not only is violence unnecessary, but it also affects a wide range of people and often involves innocent victims. This song features the typical dembow rhythm, but not all underground reggaeton followed this pattern. Reggaetón songs produced before the massive push for commercialization that began around 2004 also featured rhythms that differed from the stereotypical "dembow" such as Vico C's "La Recta Final" [The Final Stage]. Daddy Yankee's first recorded song, 
“Donde Mi No Vengas" DJ Playero 37 features a more traditional reggae rhythm and gained immense popularity in the underground scene.

Puerto Rican colonial shame had several functions during the development of the reggaetón genre. Originally, lower class Puerto Ricans, who predominantly came from public housing projects, readily accepted the new genre because they recognized that the music was authentic and dealt with issues they struggled with (Hector interview in Chosen Few 2005). Tego Calderon coincides and adds that people from this socio-economic area were fed up with not having representation in the media. This made them view reggaeton as a chance to enter public discourse and fight against the oppressive status quo. However, not all Puerto Ricans had this initial reaction towards reggaeton. Middle class Puerto Ricans met it with resistance, which manifested in protests, censorship, and boycotts. Negron Muntaner \& Rivera (2009) explain that measures were taken to keep reggaetón off of the airwaves because of its so-called corrupting influence. Politicians even attempted to take legal actions against the genre because they believed that it promoted violence and had a relationship with the drug trade.

Ethnic identification also played a role in how the upper and middle class viewed reggaetón. Historically, many Puerto Ricans, especially those in the upper and middle class, along with politicians, have attempted to whitewash themselves (Negron-Muntaner 2004). Several scholars have concluded that Puerto Rican attempts to identify themselves with (white) Spain is a way to differentiate themselves from the United States while also appearing desirable by negating their African influence. Whitewashing is also evident in the 2000 census, where $80.5 \%$ of Puerto Ricans identified themselves as being white, versus only $8 \%$ that identified themselves as being black. NegronMuntaner (2004) argues that these results show "a clear example of how racism...informs self-identification within parameters that are different from American ones" (212). These trends in ethnic identity were initially detrimental to the acceptance of underground reggaetón in Puerto Rico. Reggaetón, with its suggestive beats and African rhythms, coupled with an association with the lower classes and its subversive nature, was difficult for many Puerto Ricans to initially accept.

A function of Puerto Rican colonial shame is to promote Puerto Rican ethno-national pride and superiority in order to counter "American claims of Puerto Rican racial inferiority" (Negron-Muntaner, 2004, 16). Julio Morales analyzed in depth the discrimination, poor salaries, high unemployment, and generally poor living conditions faced by Puerto Ricans. He found that the negative stereotypes attributed to Puerto Rican migrants were the result of neocolonial oppression, which controlled the ideological discourse of American culture and politics during the first half-century after the American invasion. Eugene Mohr states that "among the nation's ethnic groups they are distinguished by a long list of negatives: lowest family incomes; highest percentage of low-level jobs; and homes without breadwinners; and the highest rate of school dropouts and of deaths from homicides, accidents, drug abuse, and cirrhosis of the liver" (xi). Therefore, the initial reaction against reggaetón by middle and upper class Puerto Ricans was an attempt to distance themselves from the negative connotations of the genre and to make themselves appear more favorable in the media.

Puerto Rican ethno-nationalism with regards to reggaetón manifested itself clearly in the period between 2004 and 2006 during the worldwide reggaetón craze. Puerto Ricans named themselves the main proponents of the genre and gave reggaetón a favored position within their culture. LeBron (2011) claims that after the "death of salsa" and reggaetón's success in international music markets, the genre became repositioned as Puerto Rico's national music, or "the new acoustic scaffolding of the nation" (222). Rivera and Negron-Muntaner (2009) identify the public's shift in acceptance of reggaetón with the 2003 political campaigns, where

el cuerpo político cambió sutilmente de bando. Durante ese periodo, se volvió muy común ver a políticos en plena campaña bailando patitiesos en su esfuerzo por mostrarle al electorado joven que ellos estaban al día con la moda. Ya para 2007, cuando la cantante pop mexicana Paulina Rubio expresó que su sencillo de reggaetón era un tributo a Puerto Rico ya que «está claro que el reguetón es de ustedes», y nadie protestó, el escritor Juan Antonio Ramos declaró que la guerra contra el reggaetón había acabado. «Hace cinco o siete años atrás tal afimación habría sido tomada no solo como un lamentable desatino, sino como un monumental insulto a la dignidad del pueblo puertorriqueño», escribió Ramos sobre la afirmación de Rubio. «El éxito del reguetón es tal que se ha quedado sin detractores (...) No sería exagerado decir que hablar mal del reguetón es casi un sacrilegio. Es casi ser un mal puertorriqueño.»[5]

However, this patriotic fever died down once the homogenization process was completed and Puerto Ricans began to hear the critiques against reggaetón by the media. There are numerous articles in El Nuevo Dia [The New Day] (the most popular newspaper on the island) that brutally attacked reggaetón. In keeping with the theory of Puerto Rican shame, audiences began to reject the genre because of the negative associations with it. According to 
Negron Muntaner (2004), Puerto Ricans strive to show the world how great their "country" is in order to subvert the shame of their colonialism and history of facing oppressors with passivity. Reggaetón, before its widespread commercialization, was touted as a product that represented the ingenuity and worth of the Puerto Rican people. The culture industry changed the genre, which caused the Puerto Rican population to no longer want to be associated with it. There are numerous articles published in Puerto Rican newspapers and online that present Puerto Ricans critiquing reggaetón.

The culture industry changed the nature of reggaetón and made it one-dimensional, like it did with hip-hip, as explained by Hart (2009). Instead of promoting varied lyric content and innovation, homogenization of the reggaetón genre was prescribed in order to maintain hegemony and gain corporate profits outside of the Puerto Rican diaspora. The dembow rhythm was standardized and artists began to join major record labels such as Universal Music Group, which produced Daddy Yankee's breakthrough CD “Barrio Fino” [Fancy Neighborhood]. After the homogenizing influence of the culture industry, popular reggaetón songs promoted the stereotypical image of underprivileged Puerto Ricans who endorsed violence, were extremely sexualized, and participated in illegal activities.

A cursory look at the Puerto Rican artists with the most \#1 hits in the Latin Rhythm Albums Chart proves this point. Daddy Yankee in Barrio Fino had hits other than "Gasolina" that portray unfavorable images of Puerto Ricans such as "Dale Caliente," which glamorizes criminal behavior, and "No Me Dejes Solo" and "Lo que Paso Paso," which refer to women in a vulgar manner.[6] Barrio Fino: En Directo features the hit single "Rompe" which describes a confrontation between two drug dealers at the club.[7] Wisin y Yandel, the reggaeton duo with the most number one singles of this category also feature degrading stereotypes. In their albums, Pa'l Mundo and Tomando el Control: Live the duo sing to women in a constant sexualized way while also glamorizing drug trafficking in their music videos, particularly for their song "El Telefono.[8]” Don Omar is also a reggaetón heavyweight, especially with the success of his albums Reggaetón Latino and King of Kings. In the song, "Reggaeton Latino," Don Omar tells a woman to let herself go and have sex with him while in "Dile" he accuses a woman of being a cheater for sleeping with him while having a boyfriend and claims that she has no excuse for her actions. He finally implores her to sleep with him again. These themes are also repeated in his songs "Salio el Sol” and Belly Danza." [9]

Rossman (2015) explains that in order for songs (and new genres) to be successful, they must fit into one of the pre-established genres. The more a song fit a particular mode, the more airplay and popularity it would have. He claims that "a program director or music director who is evaluating a song is evaluating it in terms of its relevance to the station's format... Format so completely structures radio that its effects reach upstream into the music recording industry" (72). This directorial control over the production of commercialized reggaetón is unfavorable to Puerto Ricans because, as Hart (2009) describes, audiences eventually reach the point where they are "unable to separate themselves from the scripted reality of the culture industry, individuals move in tandem with the dominant ideologies that reinforce unequal social structures based on race, class, and gender" (11). Authors are removed from the pictures by big music producers and instead the directors give the audience music that caters to their already pre-established beliefs. Puerto Rico is a small island with only a few million people on the mainland. Reggaetón directors and authors who wanted to cross over from the small Puerto Rican audience had to produce songs that the wider American public could relate to. This phenomenon is not exclusively tied to reggaetón. Hart and Rose made similar claims about the one-dimensional (and often stereotypical) representation of blacks in hip hop.

Therefore, after reaching mainstream success on the mainland, Puerto Rican reggaetón was initially praised by Puerto Ricans as being the next mainstream representation of their ethno-national music. Puerto Rican sentiments shifted, however, after the initial reggaetón boom of the early 2000s due to the negative associations that became standard for the genre. This genre that became a spectacle that promoted Puerto Rican ethno-national superiority became instead a hegemonic force that reinforced historically negative ideologies. This caused the function of colonial shame to shift from promoting ethno-national pride to rejecting the genre in order to turn away from the negative associations of the genre.

There have been several attempts by the media to explain the decline of reggaeton's popularity among the Puerto Rican population. Critics attack reggaetón as promoting gang violence and drug use/distribution. Gangsta Rap has likewise gained notoriety as being militant and promoting violence. However, Rose asserts that it is important to note that Gangsta Rap and hard core hip-hop are styles of protest music. The topics of their songs often reflect the reality of many listeners and serve as a method of rebellion, such as Public Enemy's "Night of the Living Baseheads" which Rose explains is a song that protests racial discrimination and crack use in the black community. Reggaetón is no different. The more hardcore version of reggaetón, called tiroreo, contains violent images and drug references, but original reggaetón artists such as Vico C and Calle 13 used their lyrics as a buffer and rebellion against oppression. 
For example, Calle 13's "Intel-Lú-Ayala" is about political injustices during Spanish and American colonialism that remain overlooked.

Reggaetón has also been critiqued for relying too much on the repetitive dembow rhythm, which fails to invite artist creativity. On the contrary, many musical genres such as country and rock use repetitive rhythms. Dembow has also been deemed by critics as overly sexual. According to Simon Frith (2011), ethnic music has usually endured this critique because of the difference between ethnic and Western musical styles. Traditional high music was regarded as one that did not need a physical reaction (such as in a classical music concert, where nobody moves). Music with African beats is different because it is more rhythmic and thus promotes a physical response from the listener.

Not all reggaetón has been chastised, however. Old school reggaetón remains in high regard among Puerto Ricans, which further coincides with the public's shift in acceptance and the culture industry's influence on the genre. Currently, reggaetón sales are down among Puerto Ricans and there is a tendency for artists to try to change reggaetón's image in order to distance themselves from the commercialized homogenous genre of the early 2000s. Music stations that once played reggaetón only re-branded themselves as música urbana and now play a mix of hip hop and reggaetón, as well as remixed popular songs. Nevertheless, when one considers Horkheimer and Adorno's (1972) culture industry thesis, it becomes clear that the so-called variations within the modern manifestation of the genre is actually a façade and only creates the illusion of choice. This change within the reggaetón industry might be too little too late to save the genre. For example, YouTube users that publish new Puerto Rican reggaetón music videos are often met with critical comments that favor an artist's "classic" songs over new ones. This is similar to what has happened to hip-hop artists, whose classic music is typically favored.

Frith (2011) explains that "Music constructs our sense of identity through the direct experiences it offers the body, time and sociability, experiences which enable us to place ourselves in imaginative cultural narratives" (124). The homogenizing effect of reggaetón, through the influence of the culture industry, led to a decrease in popularity among the Puerto Rican population due in part to the negative images that became associated with the genre. Puerto Rican colonial shame is a phenomenon that manifests itself by promoting a positive image of Puerto Ricans, a characteristic that is essential to understanding why increased commercialization and standardization of the genre was met with harsh critiques and the eventual decrease in reggaetón's popularity. Negron-Muntaner explains "identification with Boricua stars by Puerto Ricans is as much a misrecognition of their marginal location as an articulation of a desired insider status...to the extent that stars call attention to the 'contributions' of Puerto Ricans ... they also make Boricuas feel valuable — that they too have given to American culture—and hence more socially secure and less ashamed" (31). Therefore, this trend can be categorized as thwarting the masochistic tendencies of the culture industry because the denial of reggaetón among the Puerto Rican community ultimately takes a stand against the unjust way that they are portrayed by the media.

\section{Endnotes}

1. I am the person who no one understand, the demented crazy person/ the voice of the people, the friendliest person/ everything that I say will be disagreeable/ very intelligent and supposedly, not healthy/ Thanks to my insults/ children have to listen to me with adult supervision.

2. I don't conquer with a flag because I am not Christopher Columbus/ I am 100\% from the heart from The Acacias, I don't want to be the owner of no projects/ I am not a foreigner I am Puerto Rican.

3. Reggaetón has many spellings. I use this spelling because it is the most widely accepted variant in Puerto Rico. Quotes from sources that contain different spellings will remain unchanged.
4. Original lyrics: Mataron, mataron un inocente/ Volando él se fue/ Ya lo mataron su cuerpo descargado/ Y el enemigo seguí disparando/ Sus padres lloran también llora su hermano/ Y sus amigos lo quieren ver parado.../ Dios te lo dijo pero también te lo puede quitar/ Y si tu matas también te mataran/ Y me pregunto por qué mi gente se está acabando/ la vida es una y la vivimos matando/ recuerda el juicio se estará acercando .../ Héctor y Tito sufren/ al saber que muchos amigos ya cayeron

5. My translation: "Political parties have subtlety changed their stance. During this period, it was very common to see politicians dancing stiffly in the middle of their campaigns in an effort to demonstrate to young voters that they were up to date with current trends. Then in 2007, when the Mexican pop singer Paulina 
Rubio stated that her new reggaetón single was a tribute to Puerto Rico because "of course reggaetón is yours," and no one protested, the writer, Juan Antonio Ramos, declared that the war against reggaetón had finished. "It was five or six years ago that this type of affirmation would have been taken not only like a lamentable blow, but also as a monumental insult to the dignity of the Puerto Rican people," wrote Ramos in reaction to Rubio's affirmation. "The success of reggaetón is such that it has been left without naysayers (...) It would not be exaggerated to say that to talk bad about the genre is almost a sacrilege. It's like being a bad Puerto Rican."

6. Selected Lyrics:

"Dale Caliente": Que llamen al nueve-once, que es tiempo de juego/ Dígale que Yankee ahora está tirando el fuego

"No Me Dejes Solo": Canto de fresca, te gusta ir de pesca

"Lo Que Paso Paso": es una asesina ella conlleva la medicina/ engańadora que te envuelve y te domina/ una abusadora ella como sabe te devora/ y si no tienes experiencia te enamora

7. "Rompe": Que pasa, socio? Que es la que hay?/ inche buey pensaste que esto era un mami/ No voy a dar break, deja ese guille de Scarface/ Get out my way, usted no vende ni en eBay/ No das pa' na' conmigo estas Frito Lay

8. Selected Lyrics from the CD Pa'l Mundo:

Rakata: Le gusta que Wisin la jale por el pelo/ Grítalo/ (Papi, dame lo que quiero)

Noche de Sexo: Empecemos en la playa/ Terminemos en la cama/ Trae la toalla porque te vas a mojar
Selected lyrics from the CD Tomando Control Live:

El Teléfono: Quiero tocarte/ Enredarte en la red/ Ponerte a la pared, pa devorarte/ Entonces suéltate, lúcete, sedúceme/ Vamos aprovéchate/ Enciéndete, libérate y caliéntate/ pa' devorarte. The music video that accompanies this song is interesting. The song is about wanting to make love over the telephone. There are several innuendos that the duo is singing about underage girls because they reference her parent. This is also made evident in the music video because one of the models wears a skimpy school girl uniform. It should be noted that the age of sexual consent in Puerto Rico is 14. The context of the video, however, differs from the lyrics because it shows the singers (along with Hector the Father) transporting cocaine from one country to another while presenting scenes of them gambling and showing off their money.

9. Selected lyrics from the CD Reggaeton Latino:

"Reggaeton Latino": Lucete, modelo/ Coge vuelo, revulea tu pelo/ Aunque tu gato le den celos/ Eso, salvaje, rompete el traje/ No hagas aguaje, baila con lo que te traje

"Dile": Que quizás fue la noche la que te traicionó/ O el perfume de pelo lo que te cautivo/ Que ya no tienes excusas pa' tu traición/ Porque con llorar no se compone/ Entonces a mí dame otra noche

Selected Lyrics from the CD King of Kings:

"Salió el Sol": Ella baila hasta sola/ Como grande mueve la cola

"Belly Danza": Me excita bailocuras/ Te cura/ Provoca tu calentura/ Bailando La mambura caliente/ Figura. que toca el suelo con tanta soltura

\section{References}

Agger, B. (1992). Cultural Studies as Critical Theory. London ; Washington, DC: Falmer Press.

Billows, C. (2005). 5 Things You Didn't Know About Reggaeton. Retrieved from http://www.askmen.com/entertainment/ special_feature_100/101_special_feature.html

Calle 13. (2005). Intel-lu (Ayala). Calle 13 [Audio CD]. Sony U.S.

-.-. (2008) Ven y Critícame. Los De Atrás Vienen Conmigo. [Audio CD]. Sony U.S.

Chosen Few: el documental. (2005). [Sound recording]. New York, N.Y: Chosen Few Emerald Entertainment : Distributed through UBO Media Distribution.
Debord, G. (1970). Society of the spectacle. Detroit: Black \& Red.

DJ Negro. (2003). The Noise Biografía. PB Design.

Don Omar. (2006). King of Kings. Machete Music: Distributed by Universal Music Group.

---. (2005). Reggaetón Latino. Machete Music: Distributed by Universal Music Group.

Frith, S. (2011). Music and Identity. In Questions of Cultural Identity (pp. 108-128). London: SAGE Publications Ltd. 
Hart, W. E. (2009.). The Culture Industry, Hip Hop Music and the White Perspective: How One-Dimensional Representation of Hip Hop Music has Influenced White Racial Attitudes.

Hector y Tito. (1998). Violencia Musical [CD]. V.I. Music.

Horkheimer, M., \& Adorno, T. W. (1972). Dialectic of Enlightenment. New York: Herder and Herder.

Kellner, D. (2003). Media Spectacle. London ; New York: Routledge.

LeBron, M. (2011). “Con el Flow Natural”: Sonic Affinities and Reggaeton Nationalism. Women \& Performance: A Journal of Feminist Theory, 21(2), 219-233.

Marshall, W. (2008). Dem Bow, Dembow, Dembo: Translation and Transnation in Reggaetón. Song and Popular Culture, 53, $131-151$.

---. (2010). The Rise of Reggaeton. Retrieved from http://norient. com/en/stories/reggaeton/

Mohr, E. V. (1982). The Nuyorican experience: literature of the Puerto Rican minority. Westport, Conn: Greenwood Press.

Negrón-Muntaner, F. (2004). Boricua pop: Puerto Ricans and the Latinization of American Culture. New York: New York University Press.

Negron Muntaner, F., \& Rivera. (2009). Nacion Reggaeton.

N. O.R.E. (2004). Oye mi canto [Sound recording]. New York, NY: Roc A Fella Records.

Peterson, R. A. (1997). Creating country music: fabricating authenticity. Chicago: University of Chicago Press.

Playero 37, the original. (1999). [Sound recording]. S.l.: BM Records.

Quintero, M., \& Calasso, M. (2007). Nuestra Belleza Latina [Beauty Pageant and Reality Show]. Miami, FL: Univision.
Reggaeton. (n.d.). Retrieved from http://www.hiphopisland. com/Got2know/Reggaeton/Reggaeton.html

Reggaeton Music. (n.d.). Retrieved from http://www.donquijote. org/culture/puerto-rico/music/reggaeton-music

Rivera, R. Z., Marshall, W., \& Pacini Hernandez, D. (Eds.). (2009). Reggaetón. Durham: Duke University Press.

Rose, T. (1994). Black Noise: rap Music and Black Culture in Contemporary America. Hanover, NH: University Press of New England.

Rossman, G. (2015). Climbing the Charts: What Radio Airplay Tells Us about the Diffusion of Innovation. Princeton University Press.

The best of Public Enemy. (2001). [Sound recording]. NY, NY: Island Def Jam Music Group.

Vico C. (2006). El filosofo del rap: flows y liricas [Sound recording]. [Coral Gables, Fla.] : Miami Beach, FL: Venemusic; Distributed by Sony BMG Music Entertainment.

Vico C Still Holds it Down for Puerto Rico. (2006). Retrieved from http://www.latinrapper.com/featurednews54.html

Wisin y Yandel. (2005). Pa'l Mundo. [Sound Recording]: José Miguel Agrelot Coliseum. Machete Music: Distributed by Universal Music Group.

---. (2007). Tomando Control Live. [Sound Recording]: Machete Music: Distributed by Universal Music Group.

Yankee, D. (2005). Barrio Fino [Sound recording] : Universal City, Calif: El Cartel Records: Distributed by Universal Music and Video. 